\title{
PSA Antibody
}

National Cancer Institute

\section{Source}

National Cancer Institute. PSA Antibody. NCI Thesaurus. Code C112057.

Any immunoglobulin that recognizes prostate-specific antigen. 